\title{
TIMP1 wt Allele
}

National Cancer Institute

\section{Source}

National Cancer Institute. TIMP1 wt Allele. NCI Thesaurus. Code C52119.

Human TIMP1 wild-type allele is located within Xp11.3-p11.23 and is $4.5 \mathrm{~kb}$ in length. This allele, which encodes metalloproteinase inhibitor 1 protein, is involved in mediation of both extracellular matrix remodeling and cellular proliferation. 